\title{
Impact of change in body condition score in mid-late pregnancy in ewes fed a mixed diet on lamb survival and performance
}

\author{
Susan McCOARD ${ }^{1 *}$, Shen-Yan HEA ${ }^{1}$, Catherine McKENZIE ${ }^{1}$, Kirsty HAMMOND ${ }^{1}$ and Tim SMITH ${ }^{2}$ \\ ${ }^{1}$ AgResearch Limited, Grasslands Research Centre, Tennent Drive, Palmerston North 4442, New Zealand \\ ${ }^{2}$ Freestone Farm, Te Anau, Southland 9679, New Zealand \\ *Corresponding author: sue.mccoard@agresearch.co.nz
}

\begin{abstract}
The objective of this study was to evaluate the effect that body condition score of pregnant ewes fed on turnip and swede crops during mid-late gestation had on offspring survival and performance. Data were collected from 755 multiparous mixed-age ewes carrying 1-4 fetuses. Ewes grazed a turnip crop for 1 month prior to pregnancy scanning with supplementary ryegrass/clover baleage ( $\sim 75$ days gestation) followed by a swede crop with supplementary Lucerne baleage for 1 month following pregnancy scanning (to $\sim 120$ days gestation). Ewe body condition score (BCS) at mating, pregnancy scanning and pre-lambing, along with lamb survival and growth rates to weaning were recorded. Lamb survival from pregnancy scanning to tailing differed by litter size $(\mathrm{P}<0.001)$ with lower survival in litters with 3 or more lambs compared to singles and twins which did not differ. Improving BCS from pregnancy scanning to 120 days gestation had a positive effect on lamb survival irrespective of litter size and ewe age $(\mathrm{P}<0.001)$. Lamb survival in ewes $\geq 5$ years of age, irrespective of litter size, was lower $(\mathrm{P}<0.001)$ compared to 2 or $3-4$-yearold ewes, which in turn did not differ from each other. The key finding of the study was that loss in BCS from pregnancy scanning to 120 days gestation, negatively impacted on lamb survival, especially in ewes carrying 3 or more fetuses and in ewes $>5$ years of age irrespective of the number of fetuses carried. Furthermore, there was high variation in $\mathrm{BCS}$ change observed in both early and mid-pregnancy.
\end{abstract}

Keywords: fodder crops, lamb survival, body condition score, gestation.

\section{Introduction}

A key determinant of profitability and efficiency of resource use for commercial lamb meat production is the $\mathrm{kg}$ of lamb weaned per ewe. Increasing litter size is seen as a key contributor to achieving this outcome (e.g. Wang \& Dickerson 1991; Borg et al. 2007; Mackay et al. 2019). The ability to meet the nutritional demands of pregnant ewes, especially those carrying multiple fetuses, is a key factor influencing lamb survival and growth, and thus ewe production efficiency (McCoard et al. 2017).
The nutritional demand of pregnancy in ewes increases as gestation advances, particularly in multiple-bearing ewes (Nicol \& Brookes, 2007) as 75\% of fetal growth occurs in the last 6 weeks of gestation (McCoard et al. 2016). The inability of the ewe to meet the nutritional demands during late pregnancy results in mobilisation of body reserves and loss of body condition. A review by Kenyon et al. (2014) found that, in general, a positive relationship is observed between ewe body condition score (BCS) and lamb survival and growth to weaning despite variation among individual studies. Therefore, ewe BCS may be a useful onfarm tool to monitor the nutritional state of the ewe to influence lamb survival and growth.

New Zealand ruminant livestock production is largely pasture-based and aligned to seasonal pasture supply. Despite pasture providing a complete diet for grazing pregnant ewes when fed in sufficient quantities, there is a growing trend for farmers to use supplementary feeds including fodder crops (e.g. fodder beet, swedes, turnips) to maintain animal body condition in times of feed shortages, such as during winter (e.g. standard practice in Southland), or to facilitate increased stocking rates or improved animal production (Dalley \& Geddes 2012). We have previously reported that lamb birth weight and growth to weaning is reduced in twin-born lambs born to ewes grazed on fodder beet, compared to those fed ryegrass in mid-late gestation (Sandoval et al. 2017). This result is due potentially to the inability of the fodder beet diet to meet fibre and protein requirements of the pregnant ewe. However, data on the relationship between BCS and lamb survival and growth in ewes fed carbohydrate-rich crops such as swedes during pregnancy are limited.

The objective of this study was to use a high fecundity commercial flock to evaluate the relationship between maternal BCS and survival of lambs from ewes managed on swedes with ad libitum supplementary Lucerne baleage to provide additional protein from pregnancy scanning (40-70 days gestation) to $\sim 120$ days gestation followed by a pasture-based diet, and whether the observed responses differed depending on litter size and ewe age. We hypothesised that ewes fed a low-protein winter crop, such as swedes, would lose $\mathrm{BCS}$ as gestation advances due to their need to mobilise 
body reserves to meet the nutritional demands of pregnancy despite additional protein provided through ad libitum supplementary Lucerne/clover baleage. We predict that this effect would be exacerbated by litter size, and that a reduction in BCS would have negative consequences for offspring survival.

\section{Materials and Methods Data collection}

This study was undertaken using a retrospective analysis of animal performance data collected from a high fecundity ewe flock in Southland during the 2017 lambing season. All data used in this study were downloaded from Sheep Improvement Limited (SIL; www.sil.co.nz).

\section{Animal management}

The ewes ( $\mathrm{n}=771,2-8$ years old) evaluated were mated over a 34-day period with lambing from mid-September. In early pregnancy, the ewes were transitioned onto a herbicide tolerant (HT) leafy turnip (Brassica rapa) crop (Cleancrop Bulb Turnip; PGG Wrightson Seeds) supplemented with ad libitum good quality ryegrass/ clover (Lolium perene/Trifolium) baleage $(\sim 1$ month grazing up to pregnancy scanning). At pregnancy scanning (45-90 days gestation), the ewes were moved onto a HT swede (Brassica napus) crop (Cleancrop Hawkestone Swede; PGG Wrightson Seeds) supplemented with ad libitum Lucerne (Medicago sativa) baleage and maintained on the crop until $\sim 120$ days gestation ( $\sim 1$-month grazing). Following removal from the swede crop, the ewes were managed on pasture through lambing and up to weaning. Feed allowances were designed to maintain body condition of all ewes and meet the feed requirements with advancing gestation using the FeedPlus system (Everett-Hincks et al. 2013).

All ewes were pregnancy scanned using transabdominal ultrasound by a commercial operator with fetal age ( \pm 5 days) determined. This information was used to estimate lambing dates which informed the feeding management of the ewes. The fetal number was also identified and used as an estimate for the number of lambs born (birth rank/litter size). Fetal loss is typically low ( $\sim 5 \%)$ between mid-pregnancy scanning and lambing (Edwards et al. 2016; Juengel et al. 2015). Therefore, the number of lambs scanned is a relatively accurate reflection of the number of lambs born. Survival of lambs was determined through DNA parentage to establish the number of live lambs per ewe at tailing ( $\sim 3$ weeks post-partum) and weaning at $\sim 12$ weeks post-partum, and thus to calculate lamb survival. All ewes were scored for body condition (1 $=$ emaciated and $5=$ grossly fat at 0.5 intervals) at mating, pregnancy scanning (45-90 days gestation; end of turnip grazing), pre-lambing ( $\sim 120$ days gestation; end of swede grazing) and weaning (pasture grazing).

Body condition scoring was undertaken by a trained operator using the methods described by Jeffries (1961) as per standard farm practice on this commercial farm. Live weight of each lamb was recorded at tailing and weaning. All ewes received a Flexidine ${ }^{\mathrm{TM}}$ injection (Bayer Animal Health, Auckland, NZ) at pregnancy scanning to mitigate potential iodine deficiencies, and all ewes were given a Covexin ${ }^{\circledR} 10$ (MSD Animal Health, Wellington, NZ) vaccination pre-lambing according to the recommendations of the flock veterinarian. With the exception of 3 low BCS $(<2.0)$ triplet/quad-bearing ewes that were treated for ketosis, no animal health issues, or ewe deaths were reported in this flock. Feed analysis of the diets offered in this study were not available due to technical difficulties on-farm (failure of a freezer). Tabulated values from the literature (Nicol \& Brookes 2007) have been used as a proxy.

\section{Data analysis}

A generalised linear model with a logit link function was used to evaluate the relationship between lamb survival (as a proportion of the number of lambs scanned and the number of lambs present at tailing, for each ewe) and the variables ewe age, ewe BCS change, number of lambs scanned and their interactions. The ewe-age variable was categorised into three groups $(2$, 3-4 and 5+ years). The number of lambs scanned were categorised into four groups (single, twin, triplet and quadruplets/quintuplets). Quadruplets and quintuplets were grouped together as there was only three sets of quintuplets. Ewe BCS change was calculated as the difference between the ewe BCS recorded at pregnancy scanning and at pre-lambing (August).

There was a total of 771 ewes in the original dataset. Of these, 6 ewes were removed from the analysis due to having pregnancy scanning results less than the number of lambs present at tailing or weaning (thus accurate litter size data was not available), and 10 ewes were removed as they either scanned no lambs or did not have a scanning result. Thus, data from 755 ewes were used in the analysis. Within this dataset, there were 62 lambs with a weaning weight where no tailing weight recorded. These lambs remained in the analysis. Tukey's method was used for multiple comparison P-value adjustment. Statistical modelling of the relationship between BCS change and lamb survival was undertaken using R software (R Core Team, 2018).

A linear mixed effects model was used to test the effect of ewe BCS change from pregnancy scanning to pre-lambing on lamb weaning weight, using data available from 498 ewes due to missing lamb weight data. The model included the fixed effects of dam age, BCS change from pregnancy scanning to pre-lambing, 
lamb age, litter size, and the random effect of ewe. A repeated measurements linear mixed effects model was used to analyse the change in lamb weight over the three periods (tailing ( 3 weeks postpartum), weaning, and 6 months of age) for the effect of litter size $(1,2,3$, and 4). The age of the dam (in years), and the age of the lamb at tailing (in days) were used as covariates. The interaction between ewe age and lamb age at tailing was not tested. A square-root transformation of lamb weight was used to meet the assumptions of normality and homogeneity.

Analysis of lamb weaning weight was conducted using GenStat 19th edition (VSN International, 2018) and Fisher's Least Significant Differences were used to compare differences between the means.

\section{Results}

A total of $7552-8$-year-old ewes were used in this analysis. The mean live weight of these ewes for each litter size group between mating and weaning is shown in Table 1. Of these, $50 \%$ were twin- $(\mathrm{n}=375)$, $35 \%$ triplet- $(\mathrm{n}=264), 10.5 \%$ single- $(\mathrm{n}=79), 4.5 \%$ quadruplet- $\quad(n=34)$, and $0.4 \%$ quintuplet-bearing $(n=3)$. The breeding/lambing cycle of the ewes was categorised based on estimated fetal age at pregnancy scanning with ewes with fetuses estimated at 75-90 days gestation classified as cycle 1 and those at 45-70 days, cycle 2 . There were $652(86 \%)$ first-cycle ewes and $103(14 \%)$ second-cycle ewes.
Lamb survival irrespective of ewe age from pregnancy scanning to tailing (3 weeks post-partum), and pregnancy scanning to weaning at 12 weeks postpartum, grouped by litter size, is shown in Figure 1. While lamb survival did not differ between single and twin-bearing ewes, lower survival was evident in triplet-bearing ewes $(\mathrm{P}<0.001)$, with the lowest survival observed in ewes bearing 4 or more lambs $(\sim 48 \%)$. Lamb losses from tailing to weaning were very low and therefore not analysed.

Change in BCS relative to fetal number The proportion of ewes that changed or maintained BCS from mating to pregnancy scanning, and from pregnancy scanning to $\sim 120$ days of gestation is shown in Table 1. From mating to pregnancy scanning, the proportion of ewes that maintained condition was similar for all litter size groups, while the proportion of ewes losing BCS increased as litter size increased. From pregnancy scanning to $\sim 120$ days gestation, while approximately half of all the ewes carrying 1-3 fetuses maintained BCS, a greater proportion of ewes lost rather than gained $\mathrm{BCS}$ irrespective of litter size.

\section{Relationship between change in BCS and lamb survival for ewes of different ages}

Figure 2 illustrates the relationship between the change in ewe BCS between pregnancy scanning and prelambing (i.e. removal from the winter crop) around 120 days gestation and the predicted lamb survival at

Table 1 Changes in body condition score (BCS) from mating to pregnancy scanning, and from pregnancy scanning to 120 days gestation of ewes carrying different numbers of fetuses.

\begin{tabular}{|c|c|c|c|c|c|c|}
\hline \multirow[b]{3}{*}{ Number of ewes } & \multicolumn{6}{|c|}{ Number of fetuses } \\
\hline & Total & 1 & 2 & 3 & 4 & 5 \\
\hline & & 79 & 377 & 266 & 34 & 3 \\
\hline \multicolumn{7}{|l|}{ Proportion of flock } \\
\hline & \multicolumn{6}{|c|}{ Mating to pregnancy scanning } \\
\hline Gained $\geq 1$ BCS unit (\%) & 10 & 18 & 12 & 6 & 3 & 0 \\
\hline Gained 0.5 BCS unit (\%) & 29 & 30 & 35 & 23 & 9 & 0 \\
\hline Maintained BCS (\%) & 40 & 41 & 41 & 38 & 41 & 100 \\
\hline Lost 0.5 BCS units (\%) & 16 & 3 & 11 & 26 & 38 & 0 \\
\hline \multirow[t]{2}{*}{ Lost $\geq 1$ BCS unit (\%) } & 4 & 9 & 1 & 7 & 9 & 0 \\
\hline & \multicolumn{6}{|c|}{ Pregnancy scanning to 120 days gestation } \\
\hline Gained $\geq 1$ BCS unit (\%) & 1 & 0 & 0 & 3 & 0 & 0 \\
\hline Gained 0.5 BCS unit (\%) & 11 & 10 & 9 & 14 & 12 & 0 \\
\hline Maintained BCS (\%) & 51 & 53 & 51 & 52 & 38 & 0 \\
\hline Lost 0.5 BCS units (\%) & 30 & 37 & 33 & 24 & 29 & 67 \\
\hline Lost $\geq 1$ BCS unit (\%) & 7 & 0 & 7 & 7 & 21 & 33 \\
\hline
\end{tabular}




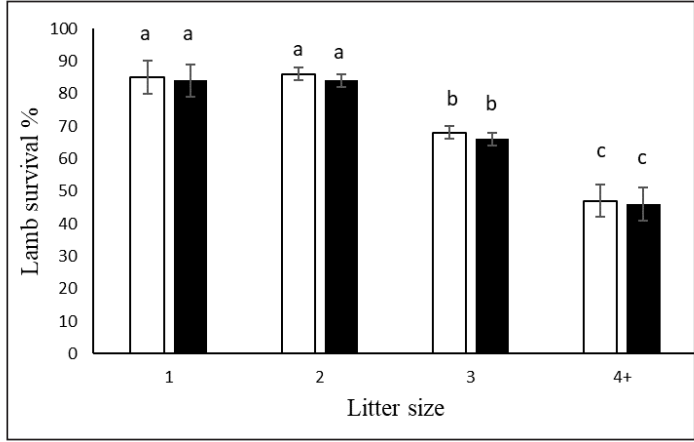

Figure 1 Survival (\%) in single (1), twin (2), triplet (3) and quadruplet/quintuplet (4) lambs from pregnancy scanning to tailing ( 3 weeks post-partum; open bars) and from tailing to weaning at 12 weeks to weaning (solid bars). Data presented are means and are adjusted for ewe age and lamb age. Superscripts depict differences between litter size groups within each measurement period.

tailing in 2 (Figure 2A), 3-4 (Figure 2B) and 5+ year-old (Figure 2C) ewes. It is important to note that the survival data from birth to tailing is based on the number of lambs born using pregnancy scanning in mid-pregnancy as an estimate. These results illustrate that predicted lamb survival is positively influenced by BCS gain from pregnancy scanning (45-90 days gestation) to $\sim 120$ days gestation irrespective of ewe age and litter size.

Improving BCS from pregnancy scanning to $\sim 120$ days gestation had a positive effect on lamb survival irrespective of litter size and ewe age $(\mathrm{P}<0.001)$. Lamb survival was lower in triplet- $(\mathrm{P}<0.001)$ and quadruplet/ quintuplet-bearing ewes $(\mathrm{P}<0.001)$, compared to singleand twin-bearing ewes but there was no difference in survival between single- and twin-bearing ewes $(\mathrm{P}=0.67)$. The predicted lamb survival in ewes $\geq 5$ years of age, irrespective of litter size, was lower $(\mathrm{P}<0.001)$ compared to 2 or 3-4-year-old ewes, which did not differ from each other $(\mathrm{P}=0.792)$. Interactions between the BCS change, ewe age and litter size were found to be non-significant $(\mathrm{P}>0.05)$. With a 1 BCS unit loss, predicted lamb survival for single and twin-bearing ewes decreased from $87-89$ to $77-79 \%$ in 2- and 3-4-year-old ewes (Figure 2A and 2B respectively) and from $\sim 78-80$ to $65-68 \%$ in $5+$ year-old ewes (Figure $2 \mathrm{C}$ ). With a 1 BCS unit loss, predicted lamb survival in tripletbearing ewes decreased from $72-73 \%$ to $57-58 \%$ in 2 and 3-4-year-old ewes (Figure 2A and B respectively) and from $59 \%$ to $42 \%$ in $5+$ year-old ewes (Figure $2 \mathrm{C}$ ). In ewes carrying 4 or 5 fetuses, predicted lamb survival decreased from $58-59 \%$ to $41 \%$ in 2- and 3-4-year-old ewes (Figure 2A and B respectively) and from $43 \%$ to $28 \%$ in $5+$ year-old ewes (Figure 2C) with a 1 BCS unit loss, with lower survival compared with both triplet- and single- and twin-bearing ewes.

\section{Lamb weaning weight}

Average ewe live weights in each litter size category at various stages of pregnancy are shown in Table 2. After adjusting for the effects of ewe and lamb age, ewe BCS change from pregnancy scanning to pre-lambing ( $\sim 120$ days gestation) had no effect on lamb live weight at weaning $(\mathrm{P}=0.826)$. Litter size $(\mathrm{P}<0.001)$, ewe age $(\mathrm{P}<0.001)$ and lamb age $(\mathrm{P}<0.001)$ influenced the weight of the lambs at tailing, weaning and at 6 months of age. There was an inverse relationship between litter size and live weight at tailing, weaning and 6 months (Figure 3).

\section{Discussion}

A positive relationship between lamb survival and gain in BCS from pregnancy scanning to $\sim 120$ days gestation was determined in this study from retrospective analysis of a dataset from ewes grazed on swedes in situ with supplementary Lucerne balage. This result is consistent with prior observations in pasture-fed ewes where improving live weight gain or BCS in mid-late pregnancy, particularly after 100 days gestation, can improve survival of lambs from Merino ewes carrying one or two lambs (Oldham et al. 2011), and in triplet-bearing ewes (Everett-Hincks et al. 2013) managed on pasture. While previous studies have suggested that maintaining a BCS of 3.0 throughout pregnancy provides the optimum outcome for ewe (Morgan-Davis et al. 2008) and lamb survival (EverettHincks et al. 2004; Jones et al. 2011), the present study suggests that avoiding BCS loss throughout pregnancy, irrespective of the initial BCS, is also important to support lamb survival. The change in BCS of the ewes from pregnancy scanning to $\sim 120$ days gestation had no effect on lamb growth to weaning. Litter size was the primary factor affecting lamb growth up to 6 months of age which is consistent with prior studies (e.g. Afolayan et al. 2007; McCoard et al. 2017). Maternal BCS during

Table 2

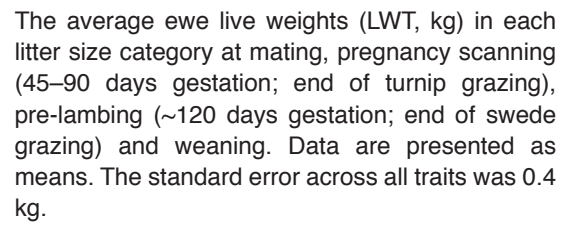

\begin{tabular}{lcccc}
\hline $\begin{array}{l}\text { Number of fetuses scanned } \\
\text { Number of ewes }\end{array}$ & 1 & 2 & 3 & $4-5$ \\
\hline Mating LWT & 79 & 375 & 265 & 37 \\
Scanning LWT & 81 & 82 & 88 & 91 \\
Pre-lamb LWT & 82 & 86 & 93 & 97 \\
Weaning LWT & 82 & 73 & 76 & 82 \\
\hline
\end{tabular}


A

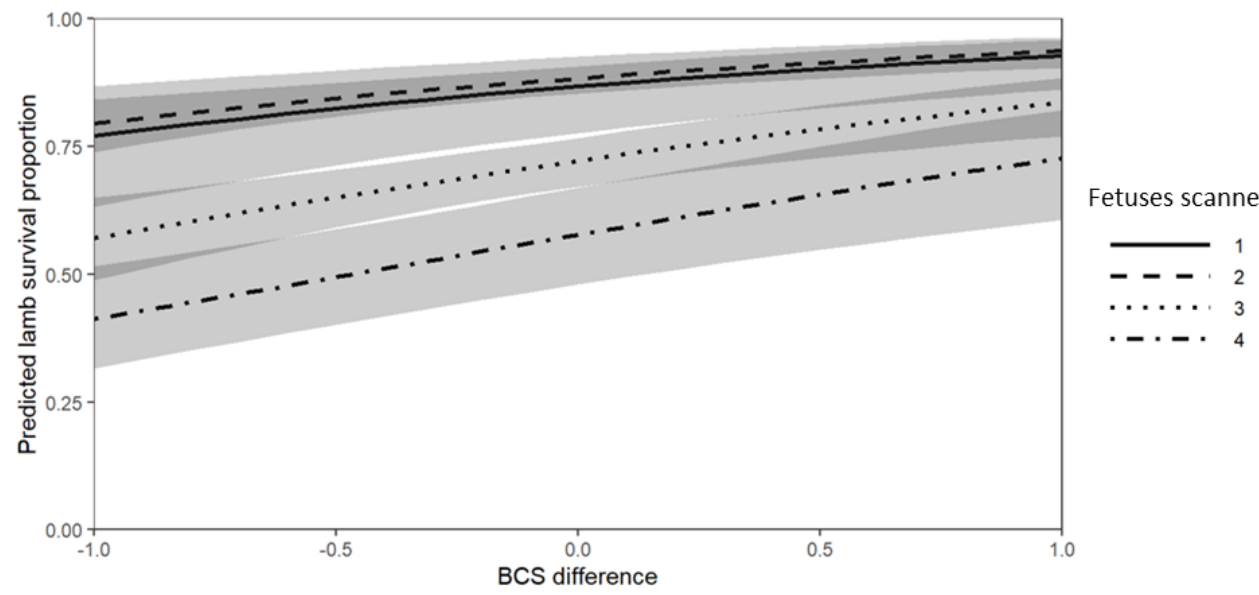

B

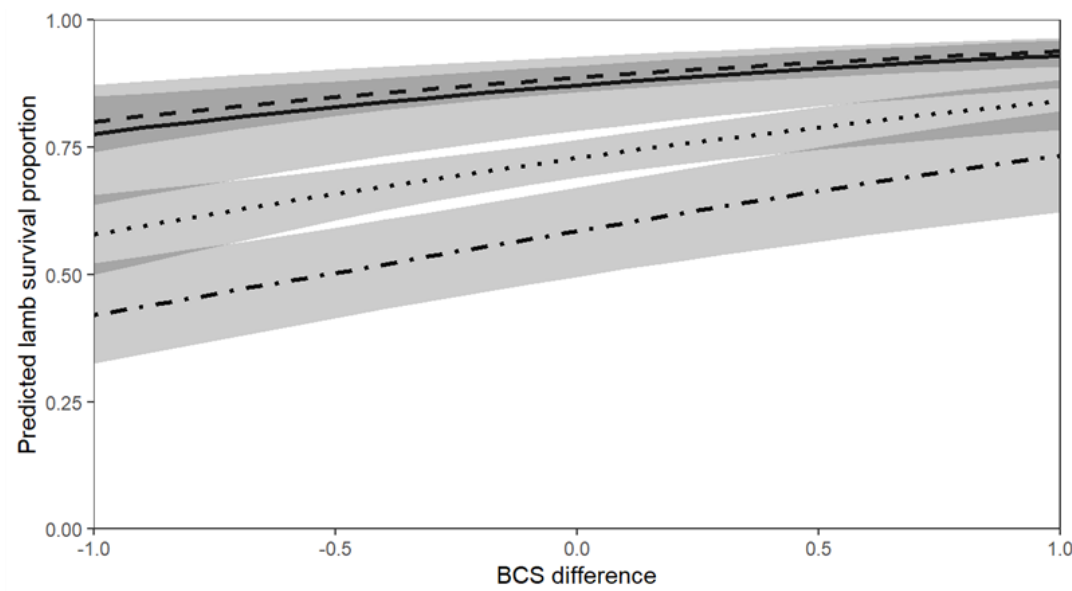

Fetuses scanned

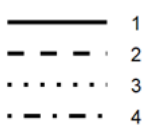

C

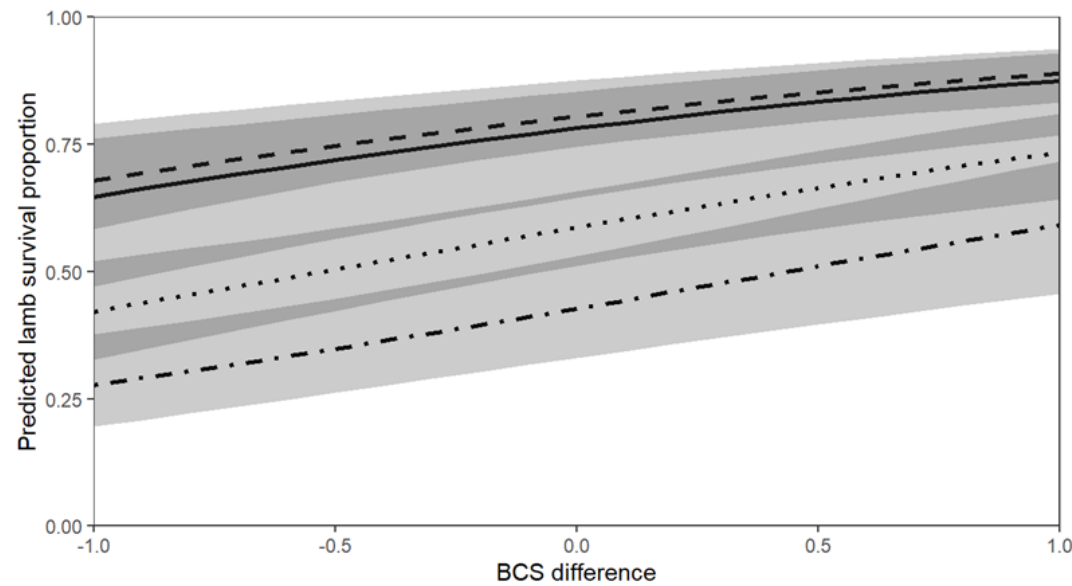

Fetuses scanned

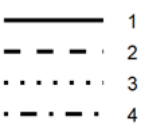

Figure 2 Predicted relationship between the change in ewe body condition score (BCS) between pregnancy scanning and removal from the winter crop around 120 days gestation and predicted lamb survival in single (1), twin (2), triplet (3) and quadruplet/quintuplet-bearing (4) 2-year-old (A), 3-4-year-old (B) and 5-year-old ewes (C). The grey shaded areas indicate the confidence limits for each litter size with the dark grey indicating the overlapping confidence limits. 


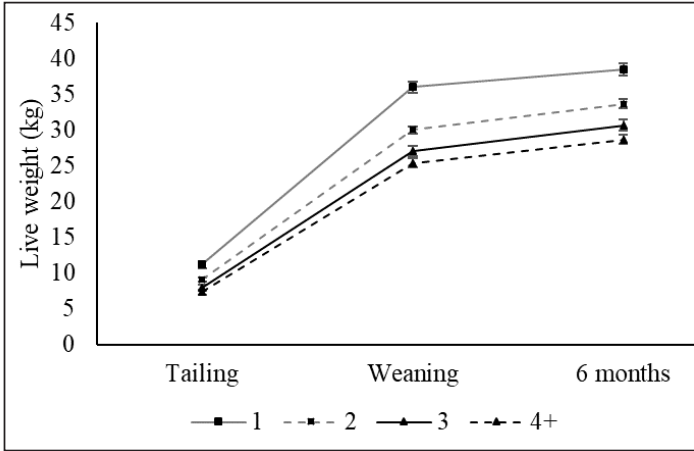

Figure 3 The effect of litter size (1, single; 2, twin; 3, triplet; $4+$, quadruplet/quintuplet) on live weight at tailing ( $\sim 3$ weeks of age), weaning ( 12 weeks of age) and 6 months of age. Data are presented as mean \pm standard error. There was a significant effect of litter size $(P<0.001)$, ewe age $(P<0.001)$ and lamb age $(\mathrm{P}<0.001)$.

lactation can influence lamb growth to weaning in ewes bearing triplets (Mathias-Davis et al. 2011) however changes in BCS during lactation was beyond the scope of the present study.

The present study highlights the greater impacts of BCS loss or gain on lamb survival as litter size increases. It is well established that greater lamb losses are associated with increased litter size (e.g., reviews by McCoard et al. 2017; Sinclair et al. 2016; Kenyon et al. 2019) which is consistent with the results of the current study. In the present study, $<10 \%$ of ewes carrying 1-3 fetuses and $<20 \%$ of ewes carrying $4+$ fetuses lost $\geq 1$ BCS units, and a further $25-40 \%$ of the ewes had a reduction in BCS of up to 1 BCS unit from pregnancy scanning to $\sim 120$ days gestation, independent of the number of fetuses carried. These results indicate that the nutritional requirements of the ewes were not met during this timeframe, especially in ewes carrying multiple fetuses, despite meeting the theoretical expected requirements of the ewes (Agricultural and Food Research Council (AFRC) 1993; FeedPlus, Everett-Hincks et al. 2013). The potential for fodder crops to not meet the nutritional requirements of pregnant ewes in mid-late gestation is consistent with the observation that progeny of twin-bearing ewes grazed on fodder beet in midlate gestation have lower lamb birth weight $(\sim 0.5$ $\mathrm{kg}$ ) compared to progeny of ewes grazed on pasture (Sandoval et al. 2017). In that study, ewes grazed on the fodder beet diet also exhibited lower BCS and reduced carcass muscle and fat content especially after 130 days gestation (Hammond, Sandoval, McKenzie, Lees, Pacheco, McCoard, unpublished observations). The loss of body condition while grazing fodder crops (this study), suggests that the nutritional requirements of the ewes were not being met, an effect exacerbated by increased litter size. Furthermore, that loss of body condition during mid-late lactation is associated with a negative effect on lamb survival.

It is well established that maternal nutritional restriction leads to a reduction in fetal growth and lowers lamb survival, with $75 \%$ of fetal growth occurring in the last 6 weeks of gestation (McCoard et al. 2017). Thus, dietary imbalances and/or feed shortages during this important phase of fetal growth and development can adversely affect the performance of both the ewe and her offspring (McCoard et al. 2017). Body condition score is correlated not only to subcutaneous fat depth and thus energy reserves, but also muscle depth and thus protein reserves (reviewed by Kenyon et al. 2014). The metabolisable energy (ME) content of HT swedes is reported to be on average $13.8 \mathrm{MJ} / \mathrm{kg} \mathrm{DM}$ and the $\mathrm{CP}$ content is on average $13.5 \%$ of DM (Westwood \& Mulcock 2012). Therefore, the ME content of the diet is unlikely to be limiting. However, the recommended crude protein content for single-bearing ewes is no less than $11 \%$ (NRC 2007), in the range of $14-18 \%$ of DM for twin-bearing ewes (Stevens 1999). While the protein requirements of triplet-bearing ewes have not been reported, they do have $50 \%$ greater feed requirements than do ewes with singles (AFRC 1993). As a greater proportion of these ewes lost BCS, improved feeding management of the ewes through provision of additional protein may be beneficial.

In addition to total dietary $\mathrm{CP}$ content, amino acids (AA) play an important role in overall fetal growth and development as a building block for proteins as well as having signalling functions to regulate multiple physiological processes important for fetal growth (McCoard et al. 2016). Low CP diets (Hopkins 1975) and under-nourishing ewes (Berlinguer et al. 2020) can alter the profile of circulating AA and key metabolites which can impact on placental nutrient uptake and transport to the fetus. The potential for insufficient AA supply/ synthesis (notably arginine, citrulline and ornithine) in cattle fed low-protein fodder beet diets compared to ryegrass has been suggested (Pacheco et al. 2016). This is important as the arginine, in particular, plays a key role in fetal growth and development (McCoard et al. 2016) and can influence key traits important for lamb survival including brown fat deposition and activation (McCoard et al. 2014), birth weight of lambs (McCoard et al. 2013), placental development and function (van der Linden et al. 2015) and lamb growth rate and muscle mass (Sales et al. 2016). We have also recently reported from a controlled indoor study, that when tripletbearing ewes are offered a chopped fodder-beet based diet balanced for $\mathrm{CP}$, fibre, vitamins and minerals, BCS 
is maintained throughout mid-late pregnancy compared to ewes consuming a forage-based diet ( $\mathrm{Knol}$ et al. 2019). These results suggest that $C P$ and/or AA supply may be limiting. However, further investigations are warranted to determine whether intake, an imbalance/ deficiency in specific dietary components (e.g. CP, CP-ME ratio, specific AA etc.) mediate the observed phenotypic responses in outdoor grazing management systems.

As nutritional demands increase with advancing pregnancy, particularly in ewes carrying multiple fetuses (Nicol \& Brookes 2007), loss of BCS in mid pregnancy increases the risk of ewes to be able to buffer the developing fetus(es) from nutritional stress in midlate gestation resulting from environmental pressures such as feed shortages, extreme climatic conditions (Everett-Hincks \& Dodds 2007). Avoiding BCS loss in early-mid pregnancy can be achieved through feed budgeting taking into account feed quality and quantity, monitoring ewe condition throughout pregnancy, and considering differential management of ewes carrying multiple fetuses to increase lamb survival, such as through grazing alternative forages, as previously suggested for triplet-bearing ewes (Geenty 1997; Everett-Hincks et al. 2013). Furthermore, differential management of older ewes ( $\geq 5$ years) independent of litter size should also be considered. Continued attention to nutritional management up to and after lambing to meet the high nutritional demands of late gestation and onset of lactation are also important to improve lamb survival.

A limitation of this study is the inability to measure intake of the fodder crop or supplementary feeds. Therefore, it is not possible to determine whether insufficient intake (e.g. via inadequate feed allowance or inability to consume enough feed) or diet composition contributed to the observed effects on animal performance. This study also did not make a comparison with ewes managed under a pasture-based feeding system used in other regions of New Zealand, not were evaluations made over multiple years. Further investigations to generate more data on how different feeding systems influence the relationship between BCS change and lamb survival are required to help the development of feeding systems that limit BCS loss to improve lamb survival.

\section{ACKNOWLEDGEMENTS}

The authors sincerely thank Pāmu, and Focus Genetics for providing access to the animal performance data from SIL. This work was funded by the AgResearch-led Strategic Science Investment Fund (SSIF) programme with in-kind support from Pāmu.

\section{REFERENCES}

Afolayan RA, Fogarty NM, Ingham VM, Gilmour AR, Gaunt GM, Cummins LJ, Pollard T. 2007. Genetic evaluation of crossbred lamb production. 3. Growth and carcass performance of second-cross lambs. Australian Journal of Agricultural Research 58(5): 457-466. https://doi.org/10.1071/AR06310

Agricultural and Food Research Council (AFRC) (Great Britain). Technical Committee on Responses to Nutrients. 1993. Energy and protein requirements of ruminants [advisory manual]. Wallingford, Oxon, UK: CAB International.

Berlinguer F, Porcu C, Molle G, Cabiddu A, Dattena M, Gallus M, Pasciu V, Succu S, Sotgiu FD, Paliogiannis P, Sotgia S, Mangoni A, Gonzalez-Bulnes A, Carru C, Zinellu A. 2002. Circulating concentrations of key regulators of nitric oxide production in undernourished sheep carrying single and multiple fetuses. Animals 10: 65. https://doi.org/10.3390/ ani10010065

Borg RC, Notter DR, Kuehn LA, Kott RW. 2007. Breeding objectives for Targhee sheep. Journal of Animal Science 85: 2815-2829. https://doi. org/10.2527/jas.2006-064

Dalley DE, T Geddes. 2012. Pasture growth and quality on Southland and Otago dairy farms. Proceedings of the New Zealand Grasslands Association 74: 237 241. https://doi.org/10.33584/jnzg.2012.74.2870

Edwards SJ, Smaill B, O'Connell AR, Johnstone PD, Stevens DR, Quirke LD, Farquhar PA, Juengel JL. 2016. Reduced ovulation rate, failure to be mated and fertilization failure/embryo loss are the underlying causes of poor reproductive performance in juvenile ewes. Animal Reproduction Science 167: 125-132. https://doi.org/10.1016/j.anireprosci.2016.02.017

Everett-Hincks JM, Dodds KG. 2007. Management of maternal-offspring behaviour to improve lamb survival in easy care sheep systems. Journal of Animal Science 86: 259-270. https://doi.org/10.2527/ jas.2007-0503

Everett-Hincks JM, Blair HT, Stafford KJ, LopezVillalobos J. 2004. The effect of ewe nutrition on maternal behaviour score and litter survival. Proceedings of the New Zealand Society of Animal Production 64: 188-191.

Everett-Hincks JM, Stevens D, Rendel JM, Smith T. 2013. The effect of ewe prelamb condition score on triplet performance in a commercial flock. Proceedings of the New Zealand Society of Animal Production 73: 126-130.

Geenty KG. 1997. A Guide to Improved Lambing Percentage for Farmers and Advisors. Wools of New Zealand and Meat New Zealand. $128 \mathrm{p}$.

Hopkins PS. 1975. The development of the foetal ruminant. In: McDonald IW \& Warner ACI Eds. 
Digestion and Metabolism in the Ruminant. Armidale, Australia: University of New England Publishing Unit, pp.1-14.

Jefferies B. 1961. Body condition scoring and its use in management. Tasmanian Journal of Agriculture 32: 19-21.

Jones A, van Burgel AJ, Behrendt R, Curnow $\mathrm{M}$, Gordon DJ, Oldham CM, Rose IJ, Thompson AN. 2011. Evaluation of the impact of Lifetime wool on sheep producers. Animal Production Science 51: 857-865. https://doi.org/10.1071/EA08303

Juengel JL, French MC, O'Connell AR, Edwards SJ, Haldar A, Brauning R, Farquhar PA, Dodds KG, Galloway SM, Johnstone PD, Davis GH. 2015 Mutations in the leptin receptor gene associated with delayed onset of puberty are also associated with decreased ovulation and lambing rates in prolific Davisdale sheep. Reproduction, Fertility, and Development 28(9): 1318-1325. https://doi. org/10.1071/RD14382

Kenyon PR, Maloney SK, Blache D. 2014. Review of sheep body condition score in relation to production characteristics. New Zealand Journal of Agricultural Research 57: 38-64. https://doi.org/10.1080/002882 33.2013.857698

Kenyon PR, Roca Fraga FJ, Blumer S, Thompson AN. 2019. Triplet lambs and their dams - a review of current knowledge and management systems. New Zealand Journal of Agricultural Research 62(4): 399-437. https://doi.org/10.1080/00288233.2019.16 16568

Knol FW, Erichsen C, Jonker A, Sandoval E, Pacheco D, Hea SY, McCoard SA. 2019. Effect of a fodder beet or Lucerne-chaff-based diet on triplet-bearing ewe live weight, body condition score and lamb birth weight. New Zealand Journal of Animal Science and Production 79: 168-170.

Mackay AD, Scobie DR, Thodes TR, Bevantier B. 2019. Has progress been made in increasing the eco-efficiency of livestock systems? New Zealand Journal of Animal Science and Production 79: 43-55.

Mathias-Davis HC, Shackell GH, Greer GJ, EverettHincks JM. 2011. The association of ewe body condition score with weight of lamb weaned. Proceedings of the New Zealand Society of Animal Production 71: 62-65.

McCoard SA, Sales F, Wards N, Sciascia Q, Oliver MH, Koolaard J, van der Linden DS. 2013. Parenteral administration of twin-bearing ewes with L-arginine enhances the birth weight and brown fat stores in sheep. SpringerPlus 2: 1-12. https://doi. org/10.1186/2193-1801-2-684

McCoard S, Wards N, Koolaard J, Salerno MS. 2014. The effect of maternal arginine supplementation on the development of the thermogenic program in the ovine fetus. Animal Production Science 54: 18431847. https://doi.org/10.1071/AN14310

McCoard SA, Sales F, Sciascia Q. 2016. Amino acids in sheep production. Frontiers in Bioscience 1: 264288. https://doi.org/10.2741/e766

McCoard SA, Sales FA, Sciascia WL. 2017. Invited review: impact of specific nutrient interventions during mid-to-late gestation on physiological traits important for survival of multiple-born lambs. Animal 22: 1-10. https://doi.org/10.1017/ S1751731117000313

Morgan-Davies C, Waterhouse A, Pollock ML, Milner JM. 2008. Body condition score as an indicator of ewe survival under extensive conditions. Animal Welfare 17: 71-77.

Nicol AM, Brookes IM. 2007. The metabolisable energy requirements of grazing livestock. In: Rattray PV, Brookes IM, Nicol AM Eds. Pasture and supplements for grazing animals. Occasional Publication No. 14. Hamilton, New Zealand Society of Animal Production. Pp. 151-172.

National Research Council. 2007. Nutrient Requirements of Small Ruminants: Sheep, Goats, Cervids, and New World Camelids. Washington, DC: The National Academies Press.

Oldham CM, Thompson AN, Ferguson MB, Gordon DJ, Kearney GA, Paganoni BL. 2011. The birthweight and survival of Merino lambs can be predicted from the profile of live weight change of their mothers during pregnancy. Animal Production Science 51: 776-783. https://doi.org/10.1071/AN10155

Pacheco D, Waghorn GC,Dalley D. 2016. Brief Communication: Plasma amino acid profiles of lactating dairy cows fed fodder beet and ryegrass diets. Proceedings of the New Zealand Society of Animal Production. 76: 62-64.

R Core Team. 2016. R: A language and environment for statistical computing. Vienna, Austria: R Foundation for Statistical Computing.

Sales FA, Sciascia Q, van der Linden DS, Wards N, Oliver MH, McCoard SA. 2016. Intravenous maternal L-arginine administration to twin-bearing ewes, during late pregnancy, is associated with increased fetal muscle mTOR abundance and postnatal growth in twin female lambs. Journal of Animal Science 94: 2519-2531. https://doi.org/10.2527/jas.2016-0320

Sandoval E, McCoard SA, Pacheco D, Lloyd-West C, Lees S, Hammond KJ. Feeding fodder beet to ewes in mid-to-late gestation: impact on lamb size, rectal temperature, and live weights from birth to weaning. Proceedings of the New Zealand Society of Animal Production 77: 34-36.

Sinclair KD, Rutherford KMD, Wallace JM, Brameld JM, Stoger R, Alberio R, Sweetman D, Gardner DS, Perry VEA, Adam CL, Ashworth CJ, Robinson JE, 
Dwyer CM. 2016. Epigenetics and developmental programming of welfare and production traits in farm animals. Reproduction, Fertility and Development 28: 1443-1478. https://doi.org/10.1071/RD16102

Stevens, DR. 1999. Ewe nutrition: decisions to be made with scanning information. Proceedings of the New Zealand Society of Animal Production 59: 93-94.

van der Linden DS, Sciascia Q, Sales F, Wards NJ, Oliver MH, McCoard SA. 2015. Intravenous maternal L-arginine administration to twin-bearing ewes during late pregnancy enhances placental growth and development. Journal of Animal Science.
93: 4917-4925. https://doi.org/10.2527/jas.20148396

Wang CT, Dickerson GE. 1991. Simulation of lifecycle efficiency of lamb and wool production for genetic levels of component traits and alternative management options. Journal of Animal Science 69: 4324-4337. https://doi.org/10.2527/1991.69114324x

Westwood CT, Mulcock H. 2012. Nutritional evaluation of five species of forage brassica. Proceedings of the New Zealand Grasslands Association 74: 31-38. https://doi.org/10.33584/jnzg.2012.74.2881 